\title{
Inferring the in situ stress regime in deep sediments: an example from the Bruchsal geothermal site
}

\author{
Jörg Meixner ${ }^{1 *}$, Eva Schill ${ }^{2,3}$, Emmanuel Gaucher ${ }^{1}$ and Thomas Kohl ${ }^{1}$
}

\author{
* Correspondence: joerg.meixner@ \\ kit.edu \\ ${ }^{1}$ Division of Geothermal Research, \\ Institute of Applied Geosciences, \\ Karlsruhe Institute of Technology \\ (KIT), Karlsruhe 76131, Germany \\ Full list of author information is \\ available at the end of the article
}

\begin{abstract}
Background: Knowledge of the ambient state of stress is of crucial importance for understanding tectonic processes and an important parameter in reservoir engineering. In the framework of the 2,500-m deep geothermal project of Bruchsal in the central part of the Upper Rhine Graben, new evidence is presented for the stress field in deep-seated sedimentary rocks.

Methods: With a sophisticated data analysis based on the concept of critical stress ratios, we evaluate the quality and uncertainty range of earlier stress field models in the Bruchsal area. New data from borehole logging and leak- off tests in deep sediments are used to propose an alternative stress profile for this part of the Upper Rhine Graben.

Results: The revised stress field model for the Bruchsal area predicts a normal with transition to strike-slip faulting regime. Stress field perturbations and potential decoupling process within specific clay-, salt-, and anhydrite-bearing units of the Keuper can be observed.

Conclusion: By comparison with other models, we can show a regional consistency of our stress field model that is reliable throughout the central Upper Rhine Graben extending from Bruchsal in the East to the Soultz-sous-Forêts EGS site in the West.
\end{abstract}

Keywords: Upper rhine graben; Stress field; Geothermal; Rock mechanics

\section{Background}

In a regional context, the stress field is typically used for investigation of neotectonic and recent geodynamic processes. The world stress map (Heidbach et al. 2008) provides a sound database with respect to determination of fault reactivation, tectonic deformation, and related earthquake hazard (e.g., Hergert and Heidbach 2011). Moreover, stress is a key parameter in unconventional reservoir engineering. Faults and fractures that are favorably oriented and critically stressed for frictional failure often dominate fluid flow (Barton et al. 1995; Townend and Zoback 2000). In this respect, a higher resolution of the stress field is required and linear stress-depth profiles should be used with caution, as principal stress magnitudes can vary locally by topography, geological unconformities, stratifications, lithology, or geological structures like faults or fractures (Heidbach et al. 2010; Zang and Stephansson 2010). In sedimentary rocks, stress field orientation and principal stress magnitudes show significant variations depending on their rheological characteristics (Anderson et al. 1973; Cornet and Burlet 1992). Interstratification of stiff

\section{Springer}

(c) 2014 Meixner et al.; licensee Springer. This is an open access article distributed under the terms of the Creative Commons Attribution License (http://creativecommons.org/licenses/by/2.0), which permits unrestricted use, distribution, and reproduction in any medium, provided the original work is properly credited. 
clastic sediments and clay-, salt-, and anhydrite-bearing formations causes significant deviations from linear stress-depth profiles in deep sedimentary basins such as the North German basin, the Paris Basin, and in continental rift systems such as the Upper Rhine Graben (URG) (Cornet and Röckel 2012; Wileveau et al. 2007). Thus, stress measurements in sediments (orientation and magnitude) need to be evaluated with respect to the lithological characteristics of the corresponding formation, and extrapolation of measured stress values to depth should be conducted with care, especially when only few measurements are available. With this in mind and although the world stress map provides a large amount of data, determination of local stress appears often to be insufficient.

In this study, we present a methodology for stress field estimation in areas where a detailed knowledge of the local stress conditions is unavailable. The approach is applied on the example of the Bruchsal geothermal site, where a number of earlier studies have been carried out with a similar aim. We will present a comparative review of the existing data and add new unpublished data from two leak-off tests (LOT) and our resulting approach applied to the Bruchsal area.

\section{Geological setting}

Bruchsal is located in the central segment of the URG close to its Eastern boundary fault (Figure 1). The Bruchsal geothermal doublet system operates through a 1,932-m-deep injection (GB1) and a 2,542-m-deep production well (GB2). The highly fractured geothermal reservoir, located at a depth ranging between 1.8 and $2.5 \mathrm{~km}$, mainly consists of fine- to coarse-grained sandstones of the Lower Triassic (Buntsandstein) and gravelly sandstones and breccia conglomerates of the Upper Permian (Rotliegend and Zechstein). The overlying Triassic units are characterized by clay-rich formations with carbonate and dolomitic layers (Muschelkalk) and gypsum- and anhydrite-bearing layers of the Keuper.

The 300-km-long URG represents the central part of the European Cenozoic rift system (Schumacher 2002), extending over a distance of more than $1,000 \mathrm{~km}$ across central Europe. It is subdivided into a NNE-striking southern, a NE-striking central, and a NNW to N-striking northern segment (Figure 1). The evolution of the Cenozoic URG was controlled by polyphase reactivations of a complex set of crustal discontinuities of Late Paleozoic structures (Ziegler 1990). The main extensional rifting and crustal NW-SE extension started in Late Eocene (Sissingh 1998) during which Late Variscan and PermoCarboniferous crustal discontinuities were transtensionally reactivated (Schumacher 2002). The opening of the graben was controlled by a paleostress field with a $S_{\text {Hmax }}$ orientation of NNE-SSW (Ahorner 1975; Illies 1975) resulting in the development of a NE-SW to NNE-SSW striking graben. A major reorientation of the regional stress field during early Miocene times established a NE-SW-extensional to transtensional stress field with reactivated fault segments showing sinistral and dextral oblique displacements but also local inversion and contraction (e.g., Illies and Greiner 1979). The change of the regional stress field initiated a new tectonosedimentary regime. The synrift deposits and older strata in the central and southern segments were uplifted and partly eroded due to transpressional reactivation of these graben segments (e.g., Rotstein et al. 2005; Rotstein and Schaming 2011). A number of thermal anomalies in the western part of the central and northern part of the URG are linked to different structural features such as zones of uplift (Baillieux et al. 2013). 


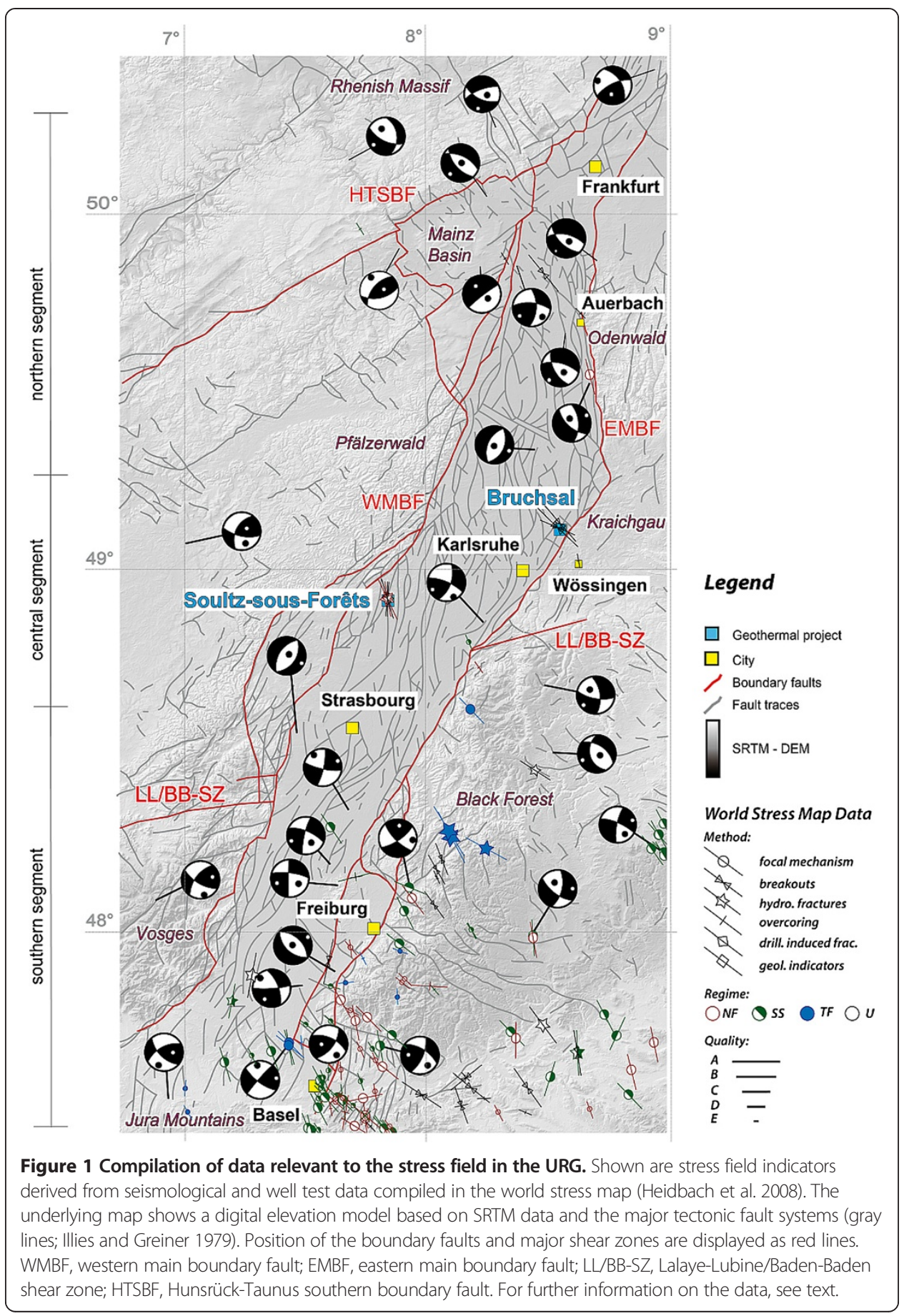

Subsidence and sedimentation were restricted to the northern graben segment with a maximum Cenozoic graben fill of up to $3.0 \mathrm{~km}$ (Bartz 1974; Pflug 1982).

Numerous local studies have been carried out to determine the tectonic stress field in the URG. Most of them are based on the analysis and interpretation of earthquakes, tectonic studies, overcoring data, hydraulic fracturing data, and borehole breakouts (Greiner 1975; Baumann 1981; Larroque and Laurent 1988; Plenefisch and Bonjer 1997; Valley and Evans 2007). Figure 1 presents an extensive data compilation for the present-day stress field in the URG and shows the abovementioned major structural units of the rift system. The 
seismological data are derived from fault plane solutions of earthquakes from 1971 to 1980 and incorporate 33 fault plane solutions selected by Larroque et al. (1987), based mostly on data from Bonjer et al. (1984). The fault traces from Illies and Greiner (1979) are based on the interpretation of 2D seismic sections. The information on the stress field orientation and the faulting regime are taken from the world stress map (Heidbach et al. 2008).

The compilation of stress field indicators in Figure 1 highlights the generally uniform NW-SE orientation of $S_{\text {Hmax }}$ demonstrated earlier by Müller et al. (1992). This general trend is confirmed by stress inversion of earthquake fault plane solutions (Delouis et al. 1993; Plenefisch and Bonjer 1997). The general trend of the stress field shows a local variation with $S_{\mathrm{Hmax}}$ orientation in the northern URG ranging $\mathrm{N} 130^{\circ} \mathrm{E}$ to $\mathrm{N} 135^{\circ} \mathrm{E}$ and in the southern URG/northern Switzerland ranging $\mathrm{N} 145^{\circ} \mathrm{E}$ to $\mathrm{N} 160^{\circ} \mathrm{E}$. Interpretations of fault plane solutions also reveal a change in faulting regime in the URG (e.g., Plenefisch and Bonjer 1997). The northern part of the URG is characterized by an extensional stress state and active normal faulting $\left(\sigma_{1}=S_{\mathrm{v}}, \sigma_{2}=S_{\mathrm{Hmax}}\right)$. In the seismically more active southern part, strike-slip faulting $\left(\sigma_{1}=S_{\mathrm{Hmax}}, \sigma_{2}=S_{\mathrm{v}}\right)$ with secondary normal faulting is the predominant mechanism. The transition of the stress orientation and the change of the faulting regime by permutation of $\sigma_{1}$ and $\sigma_{2}$ (Larroque et al. 1987) occurs in the central segment of the URG, in the area of the site of investigation, probably causing a transitional stress state between normal and strike-slip faulting.

At the western central margin of the URG, an extensive set of in situ stress data is available for the geothermal site of Soultz-sous-Forêts (France). Measured and derived orientations of $S_{\text {Hmax }}$ determined down to $5 \mathrm{~km}$ varies between $\mathrm{N} 125^{\circ} \mathrm{E}$ and $\mathrm{N} 185^{\circ} \mathrm{E}$ with a mean value of $\mathrm{N} 175^{\circ} \mathrm{E} \pm 10^{\circ}$ (Cornet et al. 2007) and indicate a transitional stress state down to $5 \mathrm{~km}$ with a change from normal to strike-slip faulting at depths below $3 \mathrm{~km}$ (Cuenot et al. 2006).

\section{Methods}

$\mathrm{S}_{\mathrm{Hmax}}$ orientation

For the Bruchsal geothermal wells, Eisbacher et al. (1989) have derived the $S_{\mathrm{Hmax}}$ orientation from borehole breakouts in GB1 and GB2 using oriented caliper logging. The logs were acquired in the depth range of 1,632 to 1,900 $\mathrm{m}$ (GB1) and 2,023 to 2,525 $\mathrm{m}$ (GB2) in the Keuper, Muschelkalk, and Buntsandstein formations and have been azimuth-corrected for the deviated wells. The values were subdivided into zones of fairly homogeneous orientation (Table 1) ranging between 50 and $100 \mathrm{~m}$ in depth. $S_{\mathrm{Hmax}}$ orientation was determined by stacking caliper data in each zone, with uncertainties of up to $20^{\circ}$. In addition to the stress-relevant data, the classification of reservoir rocks is indicated in Table 1. The italicized table entries indicate $S_{\mathrm{Hmax}}$ orientations determined in the clay-, gypsum-, and anhydrite-bearing formations of the Muschelkalk and Keuper. These low-permeable units seal the reservoir which mainly consists of sandstones and conglomerates.

\section{$S_{\mathrm{v}}$ and $P_{\mathrm{P}}$ calculation}

The magnitude of the vertical stress, $S_{v}$, is generally equal to the weight of the overburden and can be calculated by integration of the rock densities from the surface to the depth of interest. Consequently, the stratigraphic units of the overburden were subdivided in two major groups. The first group includes the quaternary and tertiary formations of the graben fill, while the second one includes the occurring Mesozoic formations. We assume an 
Table 1 Depth intervals of the analyzed borehole breakouts and determined $S_{\mathrm{Hmax}}$ orientations in wells GB1 and GB2

\begin{tabular}{llll}
\hline Well & Depth interval (MD) & Orientation of $\boldsymbol{S}_{\mathrm{Hmax}}$ & Stratigraphic formation \\
\hline \multirow{3}{*}{ GB1 } & 1,650 to $1,700 \mathrm{~m}$ & $\mathrm{~N} 104^{\circ} \mathrm{E}$ & Middle Muschelkalk and Upper Buntsandstein \\
& 1,700 to $1,775 \mathrm{~m}$ & $\mathrm{~N} 137^{\circ} \mathrm{E}$ & Middle Buntsandstein \\
& 1,775 to $1,850 \mathrm{~m}$ & $\mathrm{~N} 142^{\circ} \mathrm{E}$ & Middle Buntsandstein \\
& 1,850 to $1,900 \mathrm{~m}$ & $\mathrm{~N} 145^{\circ} \mathrm{E}$ & Lower Buntsandstein and Upper Permian \\
& 2,026 to $2,070 \mathrm{~m}$ & $\mathrm{~N} 090^{\circ} \mathrm{E}$ & Middle Keuper \\
& 2,070 to $2,130 \mathrm{~m}$ & $\mathrm{~N} 163^{\circ} \mathrm{E}$ & Lower Keuper \\
& 2,130 to $2,230 \mathrm{~m}$ & $\mathrm{~N} 125^{\circ} \mathrm{E}$ & Upper Muschelkalk and Upper Buntsandstein \\
GB2 2,250 to $2,328 \mathrm{~m}$ & $\mathrm{~N} 125^{\circ} \mathrm{E}$ & Middle Buntsandstein \\
& 2,330 to $2,385 \mathrm{~m}$ & $\mathrm{~N} 145^{\circ} \mathrm{E}$ & Middle Buntsandstein and Upper Permian \\
2,385 to $2,475 \mathrm{~m}$ & $\mathrm{~N} 131^{\circ} \mathrm{E}$ & Upper Permian \\
2,475 to $2,535 \mathrm{~m}$ & $\mathrm{~N} 128^{\circ} \mathrm{E}$ & Upper Permian \\
\hline
\end{tabular}

Formations that are not part of the reservoir are highlighted in italics.

average density of 2,400 $\mathrm{kg} \mathrm{m}^{-3}$ for the Cenozoic sedimentary succession based on Rotstein et al. (2006). For the Triassic Muschelkalk and Buntsandstein, densities were determined from a litho-density $\log$ (LDL) acquired in GB1 between 1,650 and 1,900 m (Figure 2). A weighted mean rock density of about $2,500 \mathrm{~kg} \mathrm{~m}^{-3}$ is indicated in the reservoir formations. This value is close to the literature data (Mueller 1988; Plaumann 1967). With an average thickness of the Tertiary graben sediments in Bruchsal of about $1,350 \mathrm{~m}$, a mean density of $2,430 \mathrm{~kg} \mathrm{~m}^{-3}$ for the overburden is calculated for a reservoir depth of 2,000 m. This leads to a vertical stress magnitude of $S_{\mathrm{v}}=47.7 \mathrm{MPa}$ and a gradient of $23.8 \mathrm{MPa} \mathrm{km}{ }^{-1}$.

The pore pressure, $P_{\mathrm{B}}$ was calculated similarly, assuming that it is close to hydrostatic. With an average depth of the free water table $60 \mathrm{~m}$ below ground level, the reservoir reveals tendency to slight under pressure condition. The fluid density of the geothermal brine is $1,070 \mathrm{~kg} \mathrm{~m}^{-3}$ (T. Kölbel 2013, pers. comm.). At mean reservoir depth of 2,000 m, a pore pressure of $P_{\mathrm{P}}=20.4 \mathrm{MPa}$ and a gradient of $10.2 \mathrm{MPa} \mathrm{km}^{-1}$ was calculated. This leads to a ratio of pore pressure to vertical stress magnitude of $P_{\mathrm{P}}=0.43 \cdot \mathrm{S}_{\mathrm{V}}$.

\section{Stress field profiles for Bruchsal and adjacent areas}

Eisbacher et al. (1989) prepared two different stress profiles including the minimum $\left(S_{\mathrm{hmin}}\right)$ and maximum $\left(S_{\mathrm{Hmax}}\right)$ horizontal stress components. The first stress field profile is based on the linear extrapolation of overcoring data from outcrops and shallow wells measured by Greiner (1978) hereafter referred to as the Greiner profile. In detail, the model is based on $S_{\mathrm{Hmax}}$ and $S_{\mathrm{hmin}}$ magnitudes of 4.9 and $3.7 \mathrm{MPa}$, respectively, from the 140-m-deep Auerbach well, about $60 \mathrm{~km}$ north of Bruchsal (Figure 1). These data were interpolated with measurements from the Wössingen outcrop, $10 \mathrm{~km} \mathrm{SE}$ of Bruchsal (Figure 1), with magnitudes of $S_{\mathrm{Hmax}}=2.2 \mathrm{MPa}$ and $S_{\mathrm{hmin}}=1.0 \mathrm{MPa}$. The obtained stress profile results in a normal faulting regime for the Bruchsal area of:

$$
\begin{aligned}
& \mathrm{S}_{\mathrm{Hmax}}=2.2+0.019 \cdot \mathrm{z}(\mathrm{MPa}) \\
& \mathrm{S}_{\mathrm{hmin}}=2.2+0.019 \cdot \mathrm{z}(\mathrm{MPa})
\end{aligned}
$$

The second profile is based on the stress field compilation of Rummel and Baumgärtner (1982, unpublished) for central Europe with data originating from 120 hydraulic fracturing 


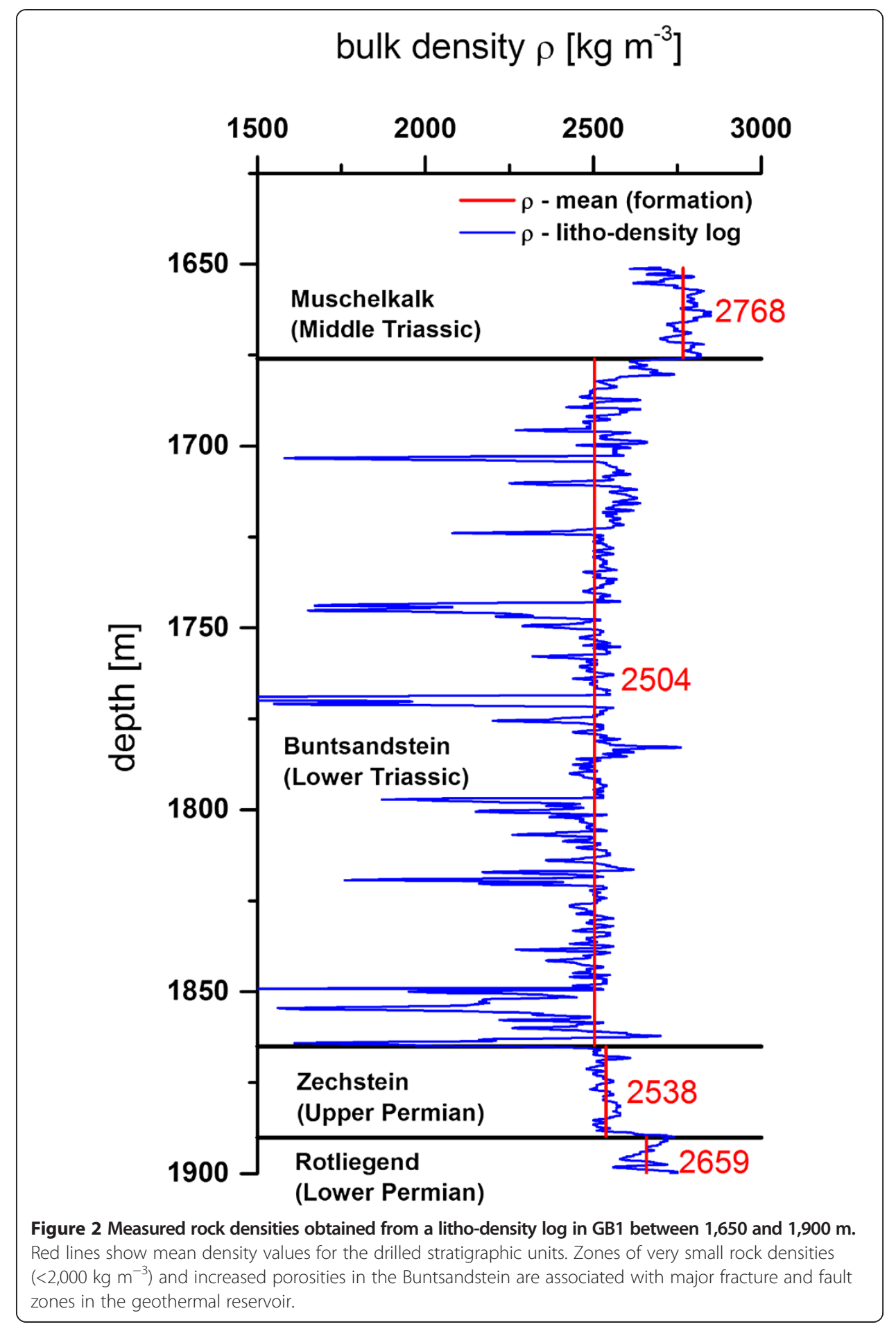

measurements. In SW Germany, this compilation is based on wells at depths down to $500 \mathrm{~m}$. The linear extrapolation (hereafter referred to as the Rummel and Baumgärtner profile) predicts a strike-slip regime with:

$$
\begin{aligned}
& \mathrm{S}_{\mathrm{H} \max }=0.8+0.034 \cdot \mathrm{z}(\mathrm{MPa}) \\
& \mathrm{S}_{\mathrm{hmin}}=0.9+0.021 \cdot \mathrm{z}(\mathrm{MPa})
\end{aligned}
$$



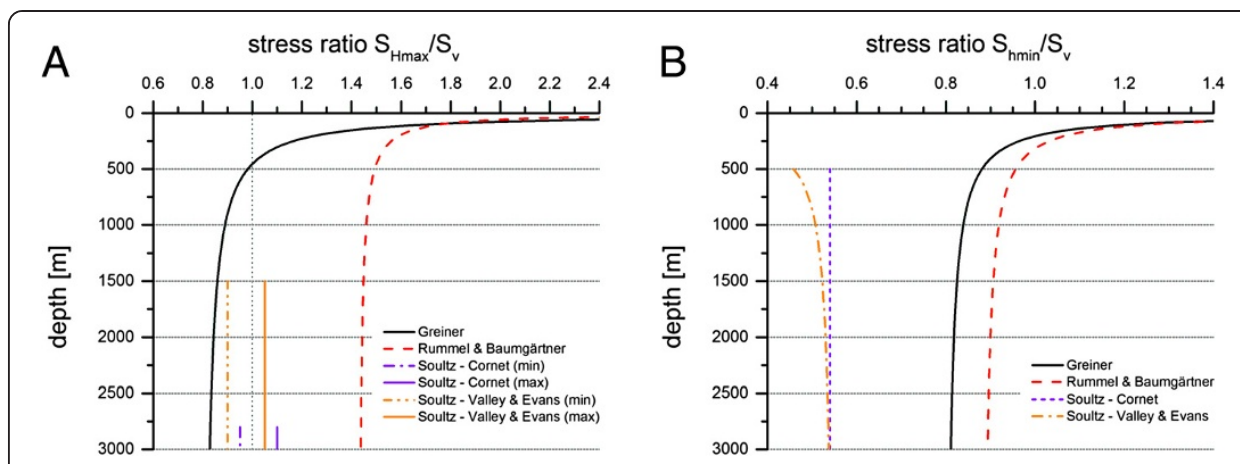

Figure 3 Comparison of existing stress-depth relationships and stress ratios for the geothermal sites of Bruchsal and Soultz. Stress magnitudes of $S_{H \max }(\mathbf{A})$ and $S_{\mathrm{hmin}}(\mathbf{B})$ are normalized by $S_{\mathrm{V}}$. The stress profiles of Greiner and Rummel and Baumgärtner are based on the combination and linear extrapolation of stress magnitudes obtained from near surface hydro frac and overcoring measurements. The Soultz stress profiles from Cornet et al. (2007) and Valley and Evans (2007) are based on evaluations of large-scale injection experiments and interpretations of borehole breakouts in the deep crystalline reservoir of Soultz.

At a reservoir depth of 2,000 m, the Rummel and Baumgärtner and Greiner profiles differ in $S_{\mathrm{hmin}}$ by $3.9 \mathrm{MPa}$ only, but in $S_{\mathrm{Hmax}}$ by $28.6 \mathrm{MPa}$. In the following, we compare these profiles to the well-defined stress field models prepared for the Soultz geothermal site. In Soultz, two profiles have been prepared recently: Cornet et al. (2007) show that the $S_{\mathrm{Hmax}}$ magnitude is close to $S_{\mathrm{V}}$ (mean $S_{\mathrm{V}}$ gradient of $24.5 \mathrm{MPa} \mathrm{km}{ }^{-1}$ ) resulting in a range of $0.95 \cdot \mathrm{S}_{\mathrm{V}}<S_{\mathrm{H} \max }<1.1 \cdot \mathrm{S}_{\mathrm{V}}$ between 2,800 and 3,600 m (Figure 3A) and Valley (2007) characterized the stress at Soultz between 1,500 and 5,000 $\mathrm{m}$ to be in the range of $0.90 \cdot \mathrm{S}_{\mathrm{V}}<S_{\mathrm{H} \max }<1.05 \cdot \mathrm{S}_{\mathrm{V}}$ (with the same $S_{\mathrm{V}}$ gradient, see Figure 3A). Both describe the transitional stress field between a normal faulting (NF) and strike-slip (SS) regime.

With exception of $S_{\mathrm{Hmax}}$ of the Greiner profile, the two Bruchsal stress profiles differ significantly from the Soultz profiles (Figure 3). With a rather similar $S_{\mathrm{v}}$ gradient of 23.8 $\mathrm{MPa} \mathrm{km}^{-1}$, the Rummel and Baumgärtner and the Greiner stress profiles would yield $S_{\mathrm{H} \max } / S_{\mathrm{V}}$ ratios at depths over $500 \mathrm{~m}$ of 1.4 to 1.5 and 0.8 to 1.0 , respectively (Figure 3A). Hence, the Rummel and Baumgärtner profile predicts a strike-slip regime, while the Greiner profile indicates normal faulting at depths below $500 \mathrm{~m}$. In contrast, the ratios of $S_{\mathrm{hmin}} / S_{\mathrm{V}}$ in both Bruchsal profiles are similar (0.8 to 0.9, see Figure 3B) but differ from the Soultz profiles with ratios of approximately 0.5 . Finally, it must be stated that the two Bruchsal profiles are debatable since they are derived from measurements at shallow depth only.

\section{Critical stress concept}

In situ measurements and detailed analyses to determine the magnitude of $\mathrm{S}_{\mathrm{Hmax}}$ are rare in the URG. In such conditions, a critical stress concept may constrain the $\mathrm{S}_{\mathrm{Hmax}}$ order of magnitude (Zoback et al. 2003). According to frictional equilibrium, one can assume that the ratio between maximum and minimum effective stresses cannot exceed the one required to cause slip on pre-existing faults that are optimally oriented to the principal stress field (Jaeger et al. 2007; Moos and Zoback 1990). Hence, effective differential stresses are bounded by a critical ratio. Assuming that one of the principal 
stresses is vertical and that there is no cohesion, the critical stress ratio can be written after Jaeger et al. (2007) as:

$$
\sigma_{1} / \sigma_{3}=\left(S_{1}-P_{\mathrm{p}}\right) /\left(S_{3}-P_{\mathrm{p}}\right) \leq(\sqrt{\mu 2+1}+\mu)^{2}
$$

where $P_{\mathrm{P}}$ is the in situ pore pressure and $\mu$ the coefficient of frictional sliding. To predict limiting stress differences at depth, Anderson's faulting theory has to be applied to determine which of the principal stresses $S_{\mathrm{Hmax}}, S_{\mathrm{hmin}}$, and $S_{\mathrm{v}}$ correspond to $S_{1}, S_{2}$, and $S_{3}$. This will depend on whether it is a normal, strike-slip, or reverse faulting regime:

$$
\begin{aligned}
& \text { Normal faulting } \quad \sigma_{1} / \sigma_{3}=\left(S_{\mathrm{v}}-P_{\mathrm{p}}\right) /\left(S_{\mathrm{hmin}}-P_{\mathrm{p}}\right) \leq\left(\sqrt{\mu^{2}+1}+\mu\right)^{2} \\
& \text { Strike-slip faulting } \quad \sigma_{1} / \sigma_{3}=\left(S_{\mathrm{H} \max }-P_{\mathrm{p}}\right) /\left(S_{\mathrm{hmin}}-P_{\mathrm{p}}\right) \leq\left(\sqrt{\mu^{2}+1}+\mu\right)^{2} \\
& \text { Reverse faulting } \quad \sigma_{1} / \sigma_{3}=\left(S_{\mathrm{H} \max }-P_{\mathrm{p}}\right) /\left(S_{\mathrm{v}}-P_{\mathrm{p}}\right) \leq\left(\sqrt{\mu^{2}+1}+\mu\right)^{2}
\end{aligned}
$$

Based on these equations, the critical ratio of the principal stress magnitudes depends on depth, pore pressure, and the coefficient of frictional sliding. A coefficient of friction of 0.85 has been shown to be applicable under shallow crustal conditions for normal stresses up to $200 \mathrm{MPa}$, i.e., depths of approximately $6 \mathrm{~km}$ (Byerlee 1978). However, it is generally accepted that hydrothermal alteration and clay content in shear planes contribute to a significant reduction of the friction angle during fault reactivation (Krantz 1991). But, since no data on the mineralogical composition of the faults and fractures in Bruchsal were acquired, we assume $\mu=0.85$, which results in an effective stress ratio of $\sigma_{1} / \sigma_{3}<4.68$. The possible mechanically stable stress conditions in different stress regimes have been comprised by Zoback et al. (2003) to the so-called stress polygon. For a given friction coefficient, the area inside the polygon represents the allowed stress, whereas values lying outside the borders are instable and yield failure.

\section{Results}

In the following, we will present the results of the determination of $S_{\mathrm{hmin}}$ by two leakoff tests from the well GB2 as well as the application of the critical stress concept to further constrain $S_{\mathrm{hmin}}$ and $S_{\mathrm{Hmax}}$.

\section{Leak-off tests and $S_{h m i n}$ magnitude}

For the determination of the least principal stress magnitude, $S_{\mathrm{hmin}}$, we interpreted new available data sets of two LOT that were carried out in 1984 (Table 2).

The leak-off pressure (LOP) at the depth of the test is the sum of the well head pressure and the pressure in the wellbore due to the wellbore fluid. According to Zoback et al. (2003), we consider the clear LOP of each test (corresponding to a distinct breakin-slope of the linear pressure build-up) to be approximately equal to the $S_{\mathrm{hmin}}$ magnitude. While LOT-2023 is conducted in the weak Keuper, LOT-2245 is located in stiff units of the Middle Buntsandstein. We would like to emphasize that LOT-2023 results in a higher LOP of $31.0 \mathrm{MPa}$ compared to LOT-2245 with a LOP of 27.6 MPa. This finding is consistent with $S_{\text {hmin }}$ magnitudes obtained in comparable environments (Cornet and Röckel 2012). The determined $S_{\mathrm{hmin}} / S_{\mathrm{v}}$ ratios show contradictory results to those from Soultz. 
Table 2 Key parameters of the two leak-off tests conducted in the geothermal well Bruchsal GB2 in 1984

\begin{tabular}{lll}
\hline & LOT-2023 & LOT-2245 \\
\hline Depth & $2,023 \mathrm{~m}$ & $2,245 \mathrm{~m}$ \\
Formation & Middle Keuper & Middle Buntsandstein \\
Drilling mud density & $1.11 \mathrm{~g} \mathrm{~cm}^{-3}$ & $1.05 \mathrm{~g} \mathrm{~cm}^{-3}$ \\
Well-head pressure & $9 \mathrm{MPa}$ & $4.5 \mathrm{MPa}$ \\
LOP $=S_{\text {hmin }}$ magnitude & $31.0 \mathrm{MPa}$ & $27.6 \mathrm{MPa}$ \\
$S_{\text {hmin }}$ gradient & $15.3 \mathrm{MPa} \mathrm{km}$ & $12.3 \mathrm{MPa} \mathrm{km}$ \\
$S_{\text {hmin }} / S_{\mathrm{V}}$, ratio & 0.64 & 0.52 \\
\hline
\end{tabular}

\section{Critical stresses of $S_{\mathrm{hmin}}$}

Based on the statements in Section 2, a normal faulting regime (NF) close to strike-slip transition is assumed for the Bruchsal area. In a first step, the $S_{\mathrm{V}}$ gradient of 23.8 $\mathrm{MPa} \mathrm{km} \mathrm{km}^{-1}$ is calculated for a mean rock density of $2,430 \mathrm{~kg} \mathrm{~m}^{-3}$. The application of the critical stress concept is illustrated in Figure 4A. Applying Equation 2, the $S_{\mathrm{hmin}}$ magnitude of LOT-2023 (15.3 $\left.\mathrm{MPa} \mathrm{km}{ }^{-1}\right)$ results in a $\sigma_{1} / \sigma_{3}$ ratio that is smaller than the critical value of $\sigma_{1} / \sigma_{3}<4.68$, whereas the $\sigma_{1} / \sigma_{3}$ ratio of LOT-2245 $\left(12.3 \mathrm{MPa} \mathrm{km}{ }^{-1}\right)$ is larger in depths over $500 \mathrm{~m}$. The latter ratio violates the critical stress concept. This may be due to errors in the determination of the $S_{\mathrm{v}}$ (in the following called upper bound) or $S_{\text {hmin }}$ (in the following called lower bound) gradient. It should be mentioned here that a higher magnitude of $\mu$ also reveals higher critical stress ratios. The interpretation of LOT-2245 $\left(S_{\mathrm{hmin}} / S_{\mathrm{v}}=0.52\right)$ leads to stress ratios between 6 and 7 at $3,000 \mathrm{~m}$ depth. In order to be consistent with the critical stress concept, a $\mu$ of 1.1 is needed. We consider this rather unlikely and discuss potential uncertainties in $S_{\mathrm{v}}$ and $S_{\text {hmin }}$ determination only.

Therefore, a sensitivity study on the rock density (or vertical stress gradient) was conducted to fit the critical stress concept. In this case, the lower bound of the

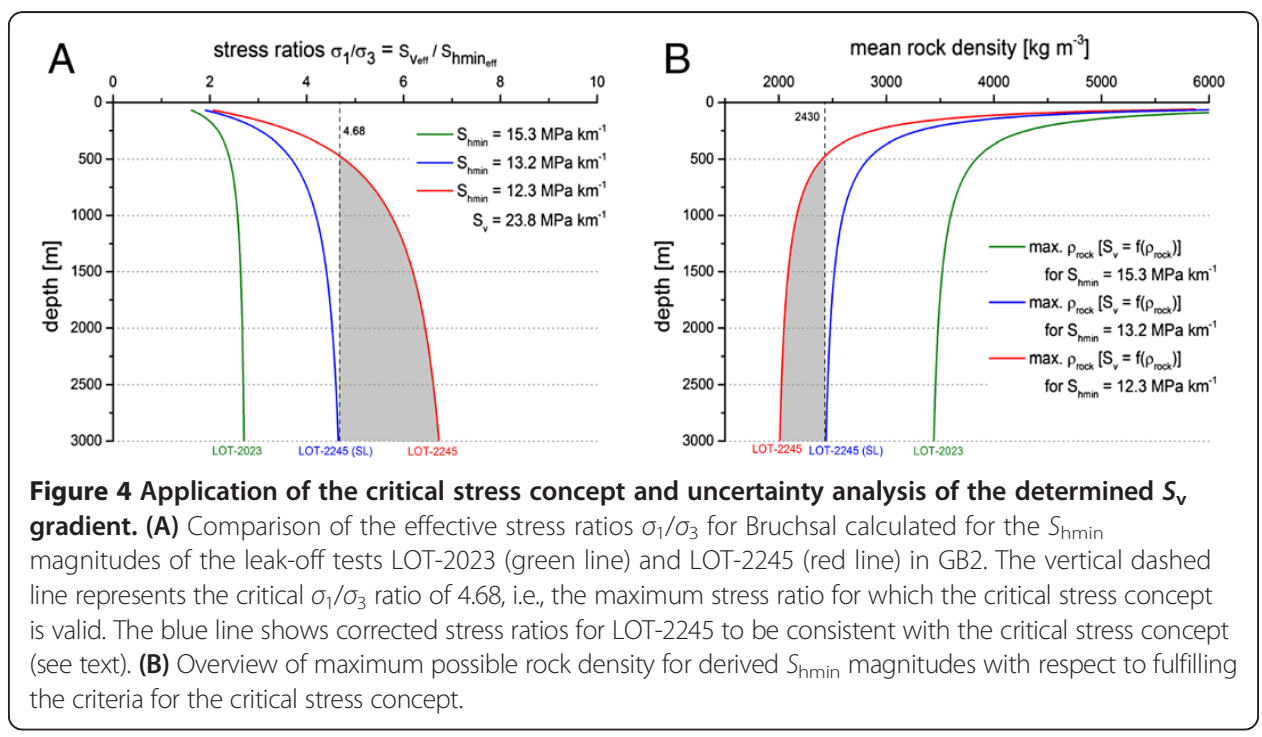


stress ratio is modified. For the $S_{\mathrm{hmin}}$ of LOT-2245, the assumed density of the overburden has to be decreased at least from 2,430 to 2,000 $\mathrm{kg} \mathrm{m}^{-3}$ (Figure 4B), yielding a decrease of the $S_{\mathrm{V}}$ gradient by $18 \%$, from 23.8 to $19.6 \mathrm{MPa} \mathrm{km}{ }^{-1}$. After comparing this value with the LDL measurements in GB2 (Subsection 3.2), we can conclude that it is unrealistically low. On the other hand, the lower bound of the ratio can be investigated, keeping the density distribution fixed. To comply with the critical stress concept, $S_{\text {hmin }}$ of LOT-2245 needs to be increased by $7 \%$, from 12.3 to $13.2 \mathrm{MPa} \mathrm{km}{ }^{-1}$. Figure 5 shows the corresponding stress profiles including the measured LOT data.

There are no error estimates given on the Bruchsal LOT measurements. Based on the example from Soultz, we can assume a reasonable uncertainty range for $S_{\text {hmin }}$ magnitudes of $\pm 0.45 \cdot \mathrm{z}[\mathrm{km}]+1.82$, as derived from several large and small volume injection tests (Valley 2007). If we assume similar error margins for Bruchsal, a bandwidth of the $S_{\mathrm{hmin}}$ profile can be determined. An increase of the $S_{\mathrm{hmin}} / S_{\mathrm{v}}$ ratio from 0.52 to 0.55 is consistent with the critical stress concept and remains consistent with the error margins determined for the deep geothermal wells in Soultz. This represents a minimum $S_{\mathrm{hmin}}$ gradient of LOT-2245, referred to as 'LOT-2245 (SL)' in the following (Figure 4, blue lines).

The hypothesis on the NF tectonic regime also influences the consistency with the critical stress concept. Following the same procedure, it is obvious that a strike-slip regime with $S_{1}=S_{\mathrm{H} \max }>S_{\mathrm{V}}$ would result in an effective stress ratio of $\sigma_{1} / \sigma_{3}>4.68$. This would rather lead to a larger increase of the $S_{\text {hmin }}$ gradient for LOT-2245 to comply with the critical stress concept. Accordingly, this option is not further considered in this study.

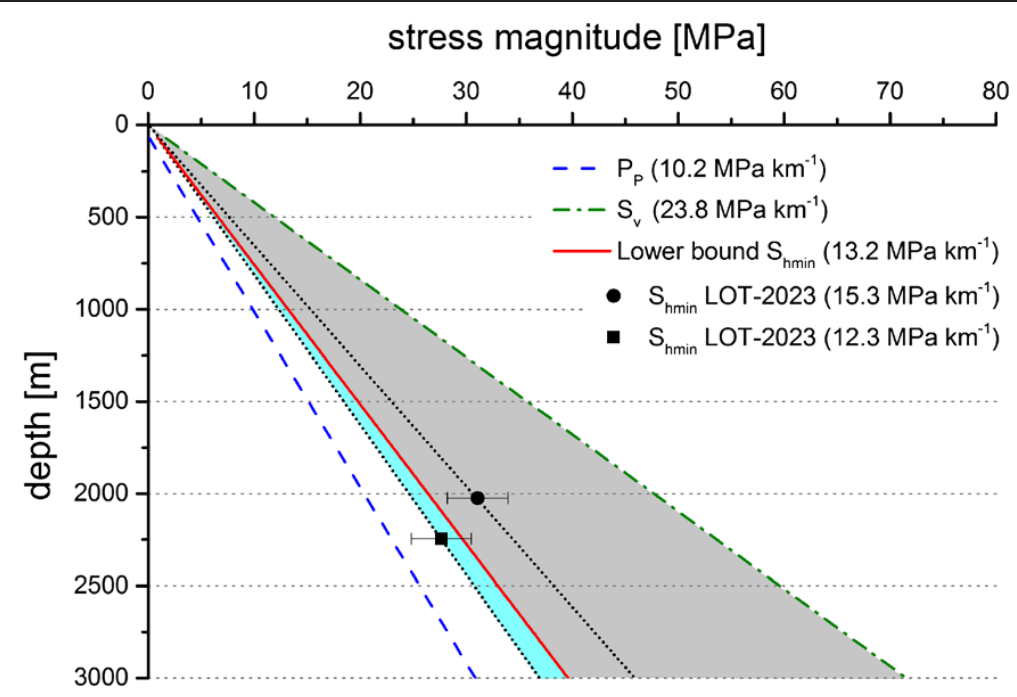

Figure 5 Uncertainty analysis of the determined $S_{\text {hmin }}$ gradients derived from LOT-2023 and LOT-2245. According to the critical stress concept, the effective stress ratio $\sigma_{1} / \sigma_{3}$ should not exceed a factor of 4.68 (gray shaded area). Assuming a $S_{v}$ gradient of $23.8 \mathrm{MPa} \mathrm{km}^{-1}$ and a NF regime, the $\sigma_{1} / \sigma_{3}$ ratio for LOT-2023 is within this range whereas LOT-2245 shows inconsistent ratios between 6 and 7. The slight increase of $S_{\text {hmin }}$ from 12.3 to $13.2 \mathrm{MPa} \mathrm{km}^{-1}$ (blue shaded area) indicates the minimum necessary variation to keep the $\sigma_{1} / \sigma_{3}$ ratio of LOT-2245 within the predicted threshold of $\sigma_{1} / \sigma_{3} \leq 4.68$. Uncertainty range of $S_{\text {hmin }}$ magnitudes is estimated following observations of Valley (2007) for deep well injection tests in Soultz. 


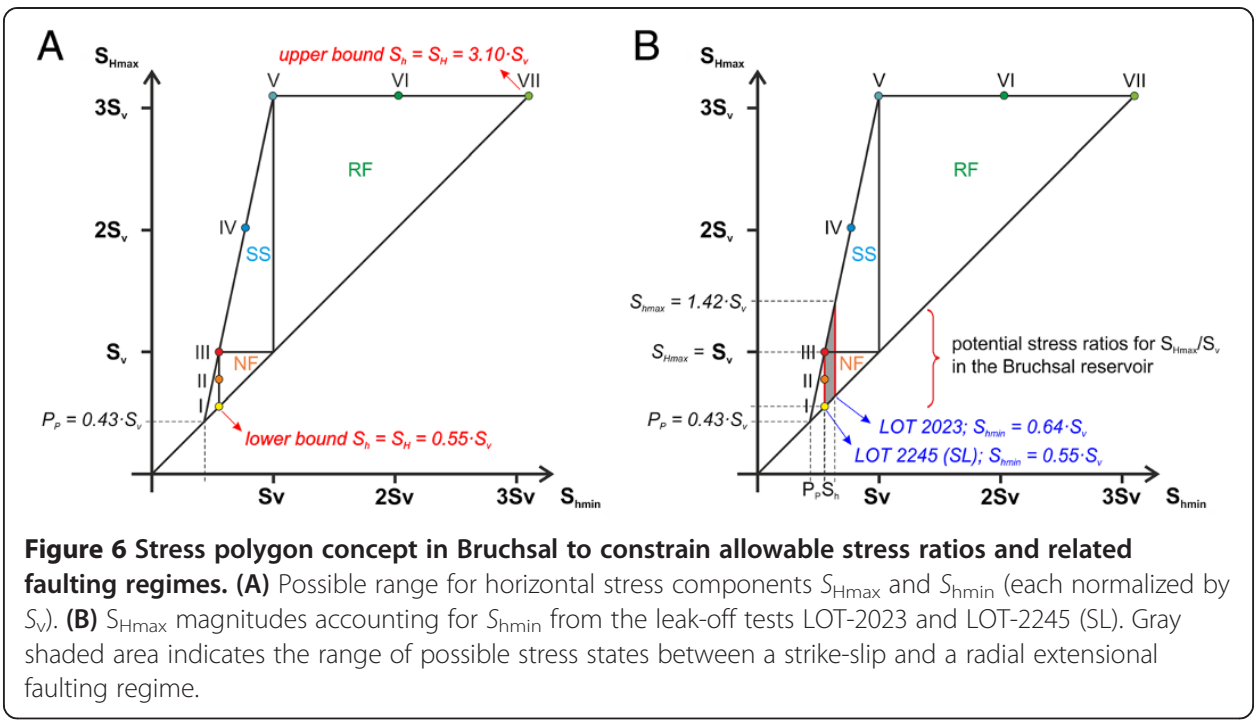

\section{Critical stresses of $S_{H \max }$}

As described by Zoback et al. (2003), the applied critical stress concept is illustrated in Figure 6 by the stress polygon. We assume a pore pressure of $P_{\mathrm{P}}=0.43 \cdot \mathrm{S}_{\mathrm{v}}$ and a frictional coefficient of $\mu=0.85$. Points at the periphery of the polygon correspond to a state of stress at the frictional limit (I, radial extension; II, normal faulting; III, transitional normal/strike-slip faulting; IV, strike-slip faulting; V, transitional strike-slip/reverse faulting; VI, reverse faulting; VII, radial compression). According to Equations 2 and 4, the lower bound on $S_{\mathrm{H} \max }$ is given by $S_{\mathrm{H} \max }=0.55 \cdot \mathrm{S}_{\mathrm{v}}$ (see previous discussion, point I in Figure 6A) and the upper bound by $S_{\mathrm{H} \max }=3.10 \cdot \mathrm{S}_{\mathrm{v}}$ (line between points $\mathrm{V}$ and VII in Figure 6A).

The range of possible values from $S_{\text {hmin }}$ (i.e., measured LOT-2023 and corrected LOT-2245 (SL)) is constrained in Figure 6B. The lower bound of $S_{\mathrm{Hmax}}$ as defined from LOT-2245 (SL) would correspond to a radial extensional faulting regime. According to our assumptions on a NF regime, $S_{\mathrm{Hmax}}$ may take any value between $S_{\mathrm{hmin}}$ and $S_{\mathrm{v}}$ (segments I to III in Figure 6B) and reaches the limit to a strike-slip regime. For LOT-2023 a stress ratio of $S_{\mathrm{H} \max }=S_{\mathrm{hmin}}=0.64 \cdot \mathrm{S}_{\mathrm{v}}$ marks the lower bound for $S_{\mathrm{Hmax}}$. With a relation of $S_{\mathrm{Hmax}}=1.42 \cdot \mathrm{S}_{\mathrm{v}}$, a strike-slip regime seems possible, too.

\section{Discussion}

The following discussion includes an assessment of the obtained stress profile in a regional context and with respect to the well-defined Soultz stress field. It should be mentioned that the sedimentary cover at Soultz reaches a maximum depth of about $1,400 \mathrm{~m}$. Consequently, at the depth of the Bruchsal reservoir at Soultz, we are already in the upper granitic reservoir (Genter et al. 2010).

\section{Stress field variations}

The orientation of $S_{\mathrm{Hmax}}$ in Bruchsal between $125^{\circ}$ and $145^{\circ}$ agrees with the general NW-SE trend of the regional stress field in SW Germany (Heidbach et al. 2008; Müller et al. 1992) and thus differs from the values in Soultz by about $30^{\circ}$ to $40^{\circ}$. This variation 


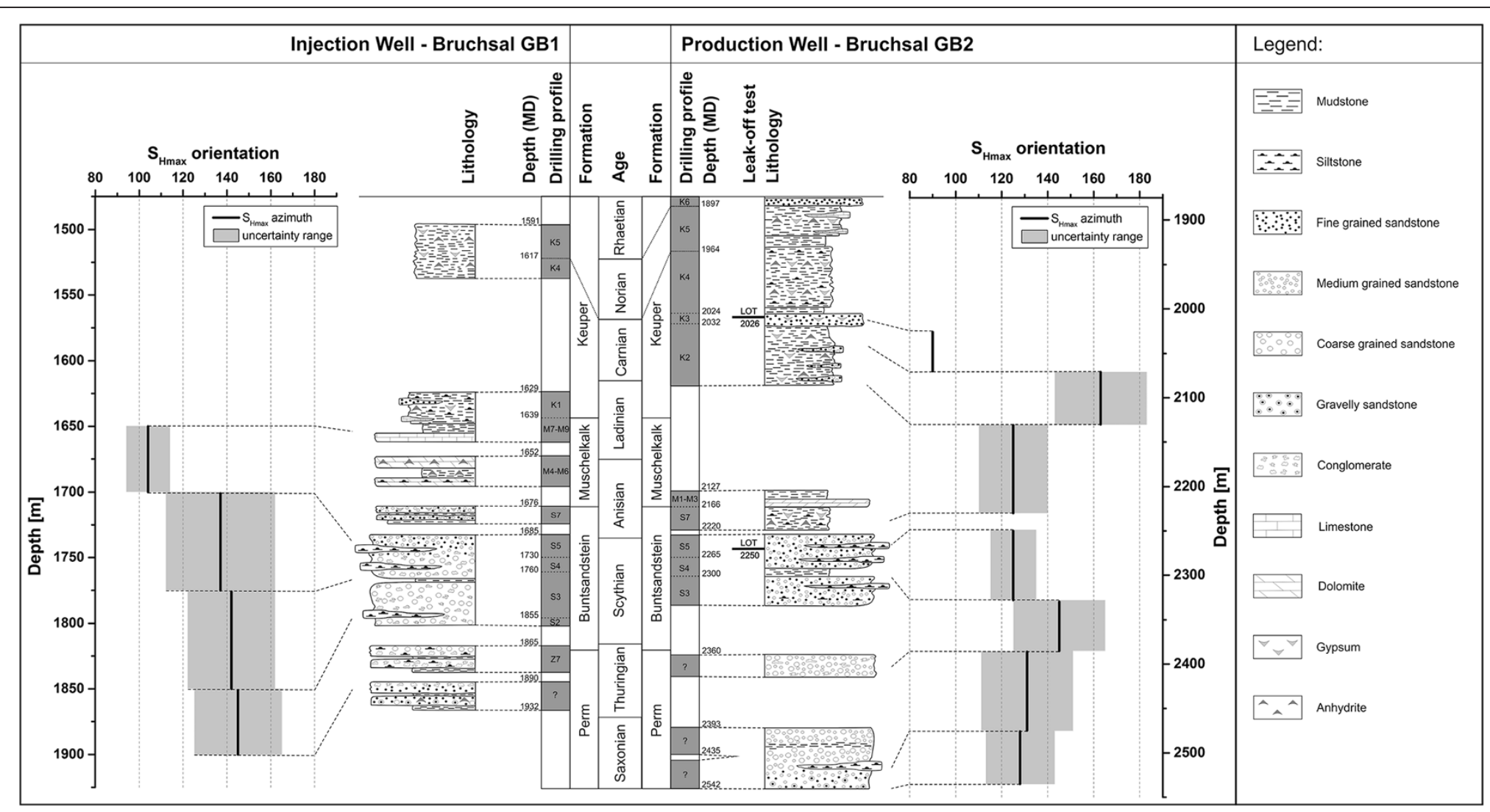

Figure 7 Comparison of the stratigraphic and lithological well profiles of the Bruchsal geothermal wells. Stress field orientations based on breakout analysis of oriented caliper logging data (Eisbacher et al. 1989). Mean $S_{H \text { max }}$ azimuths were determined by stacking breakout data in zones of fairly homogeneous orientations to take lithological characteristics into account. 
may be attributed to decoupling at the interface between the crystalline basement and the overlying sedimentary rock. Such a behavior is also observed in the Otterbach-2 well in Basel. Breakouts and drilling-induced fractures identified above and below the sediment-basement interface suggest a clockwise $30^{\circ}$ rotation of $S_{\mathrm{Hmax}}$ (Valley and Evans 2009). In Bruchsal, internal variation of orientation seems to be linked to lithological changes. A comparison of the $S_{\text {Hmax }}$ orientations for different depth sections including their variation with the litho-log of the two wells GB1 and GB2 is presented in Figure 7.

Generally, $S_{\mathrm{Hmax}}$ orientation exhibits a high variability in the upper part of the investigated section of the Mesozoic sediments. Orientations stabilize at about $140^{\circ}$ below the Muschelkalk in GB1. With the exception of the Middle Buntsandstein to Upper Permian in GB2, the orientations stabilize below the Keuper at about $130^{\circ}$. Thus, highest variation is observed for the sections with a high clay, gypsum, or anhydrite content. LOT-2023 is located in such lithology. Measured $S_{\text {Hmax }}$ orientation is by about $30^{\circ}$ to $40^{\circ}$ off the general GB2 trend in this depth range. The determined $S_{\text {hmin }}$ magnitude of LOT-2023 is 3.4 MPa higher than that of LOT-2245. This observation is consistent with results summarized by Cornet and Röckel (2012) and the increase in $S_{\text {hmin }}$ by about $4 \mathrm{MPa}$ in the Callovo-Oxfordian argillite of the Paris basin (Wileveau et al. 2007). It suggests that the leak-off tests in rocks with a low friction coefficient behave generally in this manner, which is also indicated by laboratory experiments (e.g., Krantz 1991). The stronger rocks of the Middle Buntsandstein can support higher differential

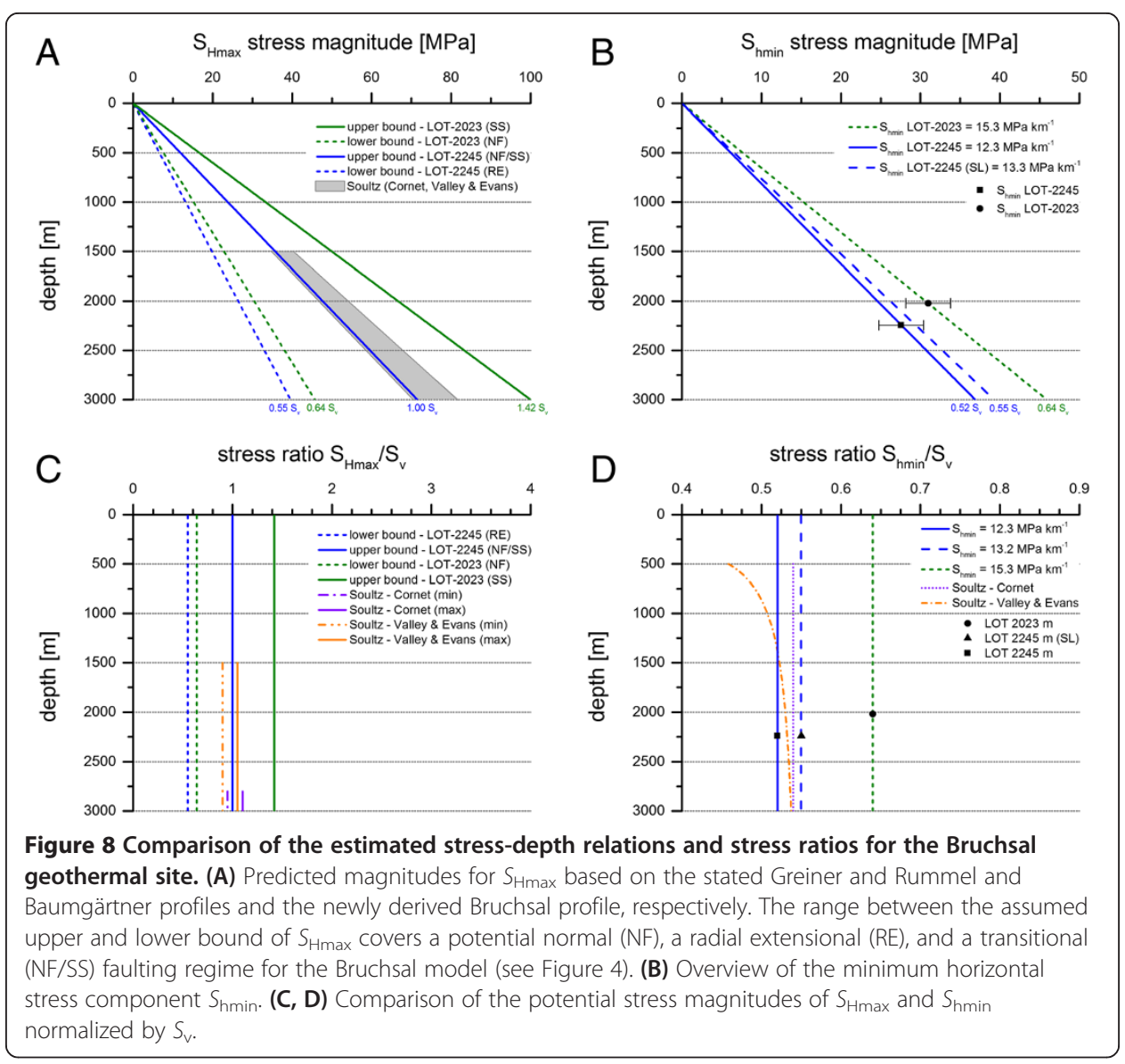


stresses without failing than the weaker rocks of the Middle Keuper. It is rather noteworthy that for the same stratigraphic unit, internal deformation processes have also been described (Wirth 1962). Litho-log interpretations of numerous oil wells of the former oil field Forst, $3 \mathrm{~km}$ North of Bruchsal, suggest massive internal shearing and sub-horizontal deformation within the Keuper and especially in the evaporitic layers of the Lower Keuper. With regard to our results, both orientation and magnitude of LOT-2023 show similar deviations and, thus, are not considered to be representative for the reservoir zone of Bruchsal. In contrast, LOT-2245 is located within the section of stable $S_{\text {Hmax }}$ orientation.

\section{Stress profile}

The discussion on the suitability of earlier stress field concepts as well as the new leakoff test data lead us to propose an alternative stress profile for the Bruchsal area that is presented in Figure 8. Our resulting stress field model is based on the LOT-2245 (SL) applying the critical stress concept. It should be mentioned that the critical stress concept restricts the ratio $\sigma_{1} / \sigma_{3}$ depending on the coefficient of frictional sliding. An increase of this ratio leads to shear failure on the most favorable oriented fault or fracture plane. We are aware that, if this fracture trend does not exist in the subsurface, larger stress ratios may be applicable. However, with no detailed information on the orientation of the fracture network, such as in Bruchsal, the application of the critical stress concept is a rather conservative approach.

Theoretically, our stress model has a $S_{\mathrm{Hmax}}$-depth relation constrained by LOT-2245 (SL) with radial extension as a lower bound faulting regime and NF/SS transition as an upper bound (Figure 8A). Geologically, the validity of the radial extension under the tectonic settings of Bruchsal is, however, questionable. As discussed in Section 2, a transitional to normal faulting stress regime in the central part of the URG in general and in Bruchsal in particular is rather likely. This is consistent with the Soultz stress profiles or determined earthquake fault plane solutions (e.g., Ritter et al. 2009). Thus, we suggest our model to be valid for NF and NF/SS faulting regimes. It should be mentioned that the Greiner profile is within our range of $S_{\mathrm{Hmax}}$ for depths larger than $500 \mathrm{~m}$.

The proposed $S_{\mathrm{hmin}}$-depth relation (Figure $8 \mathrm{~B}$ ) presents the steepest gradient (except the results for the uncorrected LOT-2245) and clearly deviates from the earlier Greiner and Rummel and Baumgärtner profiles.

Although located on the opposite side of the URG at the Eastern boundary fault and despite the different lithologies, the determined stress ratios $S_{\mathrm{Hmax}} / S_{\mathrm{v}}$ of 1.0 and $S_{\mathrm{hmin}} / S_{\mathrm{v}}$ of 0.55 for Bruchsal are close to those obtained at the same depth at Soultz (Figure 8C,D).

According to these considerations, a stress range can at best be estimated. To better constrain this, we therefore strongly recommend detailed stress measurements, such as those proposed by Cornet and Burlet (1992) in geothermal wells, in particular with respect to the option of hydraulic stimulation.

\section{Conclusions}

World-wide, geothermal projects are often located in active tectonic terrains with highly fractured subsurface reservoir rocks. The evaluation of the stress field in these projects is of main importance. It improves the understanding of the structural setting 
of the reservoir and supports the definition of an optimum exploration strategy by targeting zones of high transmissivity. The geothermal sites in the URG in central Europe are typically characterized in this context. The Rhine Graben tectonics yields large differential stress levels and favors therefore the existence of large fault and fracture systems. Due to a rather complex history, local evidence of the stress field needs to be evaluated. However, this importance of the stress field has only been pointed out gradually, and many earlier projects provide only little relevant data. In this perspective, new concepts and methodologies need to be considered. Our application of the critical stress concept to measured data may lead to better constrained results and this within their uncertainty of the measurements. The critical stress concept provides a number of solutions for the stress field model depending on possible stress regimes. Using indications such as the local geology and structural setting, the number of solutions has been reduced to normal faulting and transition of normal faulting to strike-slip regimes. Finally, based on new leak-off test data, we have constrained a new stress field model for the Bruchsal area.

Our results show that in accordance with earlier studies, sedimentary layers may have a large influence on both the orientation of the mean principal stress direction and the magnitudes. This applies in particular to clay- and anhydrite-rich layers that occur in this case in the Keuper formations and partly in the Muschelkalk. Stress decoupling and aseismic deformation within this formation cannot be excluded as also indicated by the results from the nearby Forst oil reservoir. We could show that stress magnitudes obtained in sedimentary formations vary significantly due to different rheological characteristics, and a linear stress-depth relation has to be treated only as a first approach. The result from a leak-off test in the Middle Buntsandstein in Bruchsal is, however, consistent with the $S_{\mathrm{hmin}} / S_{\mathrm{v}}$ ratio of Soultz. We may attribute this consistency across the entire E-W extension of the URG and different lithologies to small differences in the mechanical properties of the Soultz granitic basement and the sedimentary rocks of the Middle Buntsandstein in Bruchsal.

\section{Acknowledgements}

We would like to thank EnBW Energie Baden-Württemberg AG for providing the well logs and leak-off test data. Financial support has been kindly granted by the Federal Ministry for the Environment, Nature Conversation, Building and Nuclear Safety (BMU), and EnBW Energie Baden-Württemberg AG within the framework of the Logro project (FKZ 0325111 A). Further supports are from the Helmholtz Portfolio GEOENERGIE and the geothermal research center of Baden Württemberg (LFZG). We would like to thank I. Moeck, F. Cornet, B. Müller, and T. Röckel for fruitful discussions.

\section{Author details}

${ }_{1}^{1}$ Division of Geothermal Research, Institute of Applied Geosciences, Karlsruhe Institute of Technology (KIT), Karlsruhe 76131, Germany. ${ }^{2}$ GEIE, Exploitation Minière de la Chaleur, Route de Soultz, Kutzenhausen 67250, France. ${ }^{3}$ Institute of Nuclear Safety, Karlsruhe Institute of Technology (KIT), Karlsruhe 76021, Germany.

Received: 27 January 2014 Accepted: 22 April 2014

Published online: 06 June 2014

\section{References}

Ahorner L (1975) Present-day stress field and seismotectonic block movements along major fault zones in Central Europe. Tectonophysics 29(1-4):233-249

Anderson R, Ingram D, Zanier A (1973) Determining fracture pressure-gradients from well logs. Journal of Petroleum Technology 25(NOV):1259-1268

Baillieux P, Schill E, Edel J-B, Mauri G (2013) Localization of temperature anomalies in the Upper Rhine Graben: insights from geophysics and neotectonic activity. International Geology Review 1-19. doi:10.1080/00206814.2013.794914

Barton C, Zoback M, Moos D (1995) Fluid flow along potentially active faults in crystalline rock. Geology 23(8):683-686

Bartz J (1974) Die Mächtigkeit des Quartärs im Oberrheingraben. Approaches to Taphrogenesis. Inter-Union Commission on Geodynamics, Scientific report No. 8., Schweizerbart, Stuttgart, Germany. pp 78-87

Baumann H (1981) Regional stress field and rifting in Western-Europe. Tectonophysics 73(1-3):105-111. doi:10.1016/ 0040-1951(81)90177-3 
Bonjer K, Gelbke C, Gilg B, Rouland D, Mayer-Rosa D, Massinon B (1984) Seismicity and dynamics of the Upper Rhinegraben. J Geophys-Z Geophys 55(1):1-12

Byerlee J (1978) Friction of rocks. Pure and Applied Geophysics 116(4):615-626. doi:10.1007/bf00876528

Cornet F, Burlet D (1992) Stress field determinations in France by hydraulic tests in boreholes. J Geophys Res-Sol Ea 97 (B8):11829-11849. doi:10.1029/90JB02638

Cornet F, Röckel T (2012) Vertical stress profiles and the significance of "stress decoupling". Tectonophysics 581:193-205. doi:10.1016/j.tecto.2012.01.020

Cornet F, Berard T, Bourouis S (2007) How close to failure is a ganite rock mass at a $5 \mathrm{~km}$ depth? International Journal of Rock Mechanics and Mining Sciences 44(1):47-66. doi:10.1016/j.jirmms.2006.04.008

Cuenot N, Charlety J, Dorbath L, Haessler H (2006) Faulting mechanisms and stress regime at the European HDR site of Soultz-sous-Forets, France. Geothermics 35(5-6):561-575. doi:10.1016/j.geothermics.2006.11.007|10.1016/j. geothermics.2006.11.001

Delouis B, Haessler H, Cisternas A, Rivera L (1993) Stress tensor determination in France and neighboring regions. Tectonophysics 221(3-4):413-438. doi:10.1016/0040-1951(93)90171-F

Eisbacher GH, Becker A, Clauß B (1989) Geothermisches Projekt Bruchsal, Phase 5 und 6 : Tektonische Untersuchungen. Geologisches Institut und Geophysikalisches Institut, Universität Karlsruhe

Genter A, Evans K, Cuenot N, Fritsch D, Sanjuan B (2010) Contribution of the exploration of deep crystalline fractured reservoir of Soultz to the knowledge of enhanced geothermal systems (EGS). Cr Geosci 342(7-8):502-516

Greiner G (1975) In situ stress measurements in Southwest Germany. Tectonophysics 29(1-4):265-274. doi:10.1016/ 0040-1951(75)90150-X

Greiner G (1978) Spannungen in der Erdkruste: Bestimmung und Interpretation am Beispiel von In-situ-Messungen im Süddeutschen Raum. Karlsruhe

Heidbach O, Tingay M, Barth A, Reinecker J, Kurfeß D, Müller B (2008) The World Stress Map database release. doi:10.1594/GFZ.WSM.Rel2008

Heidbach O, Tingay M, Barth A, Reinecker J, Kurfess D, Muller B (2010) Global crustal stress pattern based on the World Stress Map database release 2008. Tectonophysics 482(1-4):3-15. doi:10.1016/j.tecto.2009.07.023

Hergert T, Heidbach O (2011) Geomechanical model of the Marmara Sea region-II. 3-D contemporary background stress field. Geophys J Int 185(3):1090-1102. doi:10.1111/j.1365-246X.2011.04992.x

Illies J (1975) Recent and paleo-intraplate tectonics in stable Europe and the Rhinegraben rift system. Tectonophysics 29(1-4):251-264. doi:10.1016/0040-1951(75)90149-3

Illies J, Greiner G (1979) Holocene movements and state of stress in the rhinegraben rift system. Tectonophysics 52(1-4):349-359

Jaeger JC, Cook NGW, Zimmermann RW (2007) Fundamentals of Rock Mechanics, 4th edn. Blackwell Publishing, Malden MA, USA

Krantz R (1991) Measurements of friction coefficients and cohesion for faulting and fault reactivation in laboratory models using sand and sand mixtures. Tectonophysics 188(1-2):203-207. doi:10.1016/0040-1951(91)90323-K

Larroque J, Laurent P (1988) Evolution of the stress field pattern in the south of the Rhine Graben from the Eocene to the present. Tectonophysics 148(1-2):41-58. doi:10.1016/0040-1951(88)90159-X

Larroque J, Etchecopar A, Philip H (1987) Evidence for the permutation of stresses $s 1$ and $s 2$ in the Alpine foreland the example of the Rhine Graben. Tectonophysics 144(4):315-322. doi:10.1016/0040-1951(87)90299-X

Moos D, Zoback M (1990) Utilization of observations of well bore failure to constrain the orientation and magnitude of crustal stresses: application to continental, deep-sea drilling project, and ocean drilling program boreholes. Journal of Geophysical Research-Solid Earth and Planets 95(B6):9305-9325. doi:10.1029/JB095iB06p09305

Mueller K (1988) Anwendung moderner gravimetrischen Interpretationstechniken zur Erkundung der Kruste von Suddeutschland. Ph.D., Technical Univ, Clausthal, Germany

Müller B, Zoback M, Fuchs K, Mastin L, Gregersen S, Pavoni N, Stephansson O, Ljunggren C (1992) Regional patterns of tectonic stress in Europe. J Geophys Res-Sol Ea 97(B8):11783-11803. doi:10.1029/91JB01096

Pflug R (1982) Bau und Entwicklung des Oberrheingrabens. Erträge der Forschung 184:145, Darmstadt (Wiss. Buchges.)

Plaumann S (1967) Rock density in the upper Rhine Valley. The Rhinegraben Progress Report 1967. Mem Ser Cart Ceol Alsace Lorraine 26:114-115

Plenefisch T, Bonjer K (1997) The stress field in the Rhine Graben area inferred from earthquake focal mechanisms and estimation of frictional parameters. Tectonophysics 275(1-3):71-97. doi:10.1016/S0040-1951(97)00016-4

Ritter JRR, Wagner M, Bonjer KP, Schmidt B (2009) The 2005 Heidelberg and Speyer earthquakes and their relationship to active tectonics in the central Upper Rhine Graben. Int J Earth Sci 98(3):697-705. doi:10.1007/s00531-007-0284-

Rotstein Y, Schaming M (2011) The Upper Rhine Graben (URG) revisited: Miocene transtension and transpression account for the observed first-order structures. Tectonics 30 doi:10.1029/2010tc002767

Rotstein Y, Behrmann JH, Lutz M, Wirsing G, Luz A (2005) Tectonic implications of transpression and transtension: Upper Rhine Graben. Tectonics 24(6) doi:10.1029/2005tc001797

Rotstein Y, Edel JB, Gabriel G, Boulanger D, Schaming M, Munschy M (2006) Insight into the structure of the Upper Rhine Graben and its basement from a new compilation of Bouguer Gravity. Tectonophysics 425(1-4):55-70

Schumacher ME (2002) Upper Rhine Graben: role of preexisting structures during rift evolution. Tectonics 21(1):1006. doi:10.1029/2001TC900022

Sissingh W (1998) Comparative tertiary stratigraphy of the Rhine Graben, Bresse Graben and Molasse Basin: correlation of Alpine foreland events. Tectonophysics 300(1-4):249-284. doi:10.1016/50040-1951(98)00243-1

Townend J, Zoback M (2000) How faulting keeps the crust strong. Geology 28(5):399-402. doi:10.1130/0091-7613(2000) 28<399:HFKTCS $>2.0 . C O ; 2$

Valley BC (2007) The relation between natural fracturing and stress heterogeneities in deep-seated crystalline rocks at Soultz-sous-Forêts (France). ETH Reprozentrale Hönggerberg, HIL C45, 178 Zürich (2007) http://dx.doi.org/103929/ ethz-a-005562794260

Valley B, Evans K (2007) Stress state at Soultz-sous-Forêts to $5 \mathrm{~km}$ depth from wellbore failure and hydraulic observations. In: Proceedings of the 32nd Workshop on Geothermal Reservoir Engineering. Stanford University, Stanford, CA, USA 
Valley B, Evans K (2009) Stress orientation to $5 \mathrm{~km}$ depth in the basement below Basel (Switzerland) from borehole failure analysis. Swiss J Geosci 102(3):467-480. doi:10.1007/s00015-009-1335-z

Wileveau Y, Cornet F, Desroches J, Blumling P (2007) Complete in situ stress determination in an argillite sedimentary formation. Physics and Chemistry of the Earth 32(8-14):866-878. doi:10.1016/j.pce.2006.03.018

Wirth E (1962) Die Erdöllagerstätten Badens. Abh geol 4-5, Landesamtes Baden-Württemberg, Freiburg i.Br

Zang A, Stephansson O (2010) Stress Fields of the Earth's Crust, firstth edn. Springer, Berlin. doi:10.1007/978-1-4020-8444-7

Ziegler P (1990) Collision related intra-plate compression deformations in Western and Central Europe. Journal of Geodynamics 11(4):357-388. doi:10.1016/0264-3707(90)90017-O

Zoback M, Barton C, Brudy M, Castillo D, Finkbeiner T, Grollimund B, Moos D, Peska P, Ward C, Wiprut D (2003) Determination of stress orientation and magnitude in deep wells. International Journal of Rock Mechanics and Mining Sciences 40(7-8):1049-1076. doi:10.1016/j.jijmms.2003.07.001

doi:10.1186/s40517-014-0007-z

Cite this article as: Meixner et al: Inferring the in situ stress regime in deep sediments: an example from the

Bruchsal geothermal site. Geothermal Energy 2014 2:7.

Submit your manuscript to a SpringerOpen ${ }^{\circ}$ journal and benefit from:

- Convenient online submission

- Rigorous peer review

- Immediate publication on acceptance

- Open access: articles freely available online

- High visibility within the field

- Retaining the copyright to your article

Submit your next manuscript at $\boldsymbol{\nabla}$ springeropen.com 